\title{
Antioxidative, Antiproliferative and Antiangiogenic Activities of Nigella sativa L. pulp, a Waste Material Remaining from Oil Production
}

\author{
Yağ Çıkarma Iş̧ımi Sonrasında Atık Materyal Olarak Ortaya \\ Çıkan Çörek Otu Posasının Anti-oksidan, Anti-proliferatif ve Anti- \\ anjiyojenik Özellikleri \\ Research Article
}

Gamze Tan

Department of Biology, Faculty of Science and Letters, Aksaray University, Aksaray, Turkey.

\begin{abstract}
A B S T R AC T
The aim of this study is to investigate the biological activities such as antioxidative, antimetastatic and antiangiogenic properties of the Nigella sativa L. (NS) pulp, which is a waste material of the oil production process. Following the investigation of the characteristic properties of NS pulp extract with UV-visible (UVvis), fourier-transform infrared (FTIR) and gas chromatography-mass spectroscopy (GC-MS) measurements, its antioxidative capacity was determined using 2,2-Diphenyl-1-picrylhydrazyl (DPPH) and Trolox equivalent antioxidant capacity (TEAC) assays. Antiproliferative effects of the pulp extract were tested on both cancerous and non-cancerous cells to examine whether the effects are specific to cell types. Antiangiogenic tests were performed via chick chorioallantoic membrane (CAM) assay. The results showed that the NS pulp extract still maintained its radical scavenging effects and reduced the proliferation of cancer cells more efficiently compared to non-cancerous cells. Furthermore, CAM assays demonstrated that the pulp extract effectively limited vascular endothelial growth factor (VEGF)-stimulated vascularization and development. NS pulp might be used for the suppression of the metastatic cell populations and for the treatment of the diseases particularly like cancer, which progress with pathological angiogenesis. This study highlights that such waste materials from plants can be recycled with various uses in many fields.
\end{abstract}

\section{Key Words}

Nigella sativa, cancer treatment, antiangiogenic activity, chorioallantoic membrane assay.

\section{öz}

$\mathrm{B}$ çalışmanın amacı, yağ çıkarma işlemi sonrasında atık materyal olarak ortaya çıkan çörek otu (Nigella sativa L.-NS) posasının anti-oksidan, anti-metastatik ve anti-anjiyojenik özelliklerinden yola çıkarak biyolojik etkinliklerini incelemektir. NS posasından çıkarılan özütün UV-görünür bölge (UV-vis), Fourier Dönüşümlü Kızılötesi (FTIR) ve gaz kromatografisi-kütle spektrometresi (GC-MS) ölçümleriyle karakteristiksel özellikleri incelendikten sonra 2,2-difenil- 1-pikrilhidrazil (DPPH) ve Trolox eşdeğer antioksidan kapasitesi (TEAC) yöntemleri kullanılarak anti-oksidatif kapasitesi tayin edilmiştir. Posa özütünün anti-proliferatif etkileri, etkilerin hücre tipine özgü olup olmadığını incelemek amacıyla hem kanser hem de kanser olmayan hücreler üzerinde test edilmiştir. Anti-anjiyojenik testler civciv korioallantoik membran testi (CAM) aracılığıyla gerçekleştirilmiştir. Sonuçlar NS posa ekstratının radikal süpürücü etkilerini halen muhafaza ettiğini ve normal hücreler ile karşılaştırıldığında kanser hücre proliferasyonunu daha etkin bir biçimde düşürdüğünü göstermiştir. Ayrıca CAM testleri NS posa özütünün VEGF uyarımlı vaskülarizasyon ve gelişimini etkin bir biçimde sınırladığını göstermiştir. NS posa özütü metastatik hücre topluluklarının baskılanmasında ve kanser başta olmak üzere patolojik anjiyogenez ile seyreden hastalıkların tedavisinde faydalı sonuçlar üretebilir. Bu çalışma bitkisel kaynaklı atık maddelerin birçok alanda çok çeşitli amaçlar doğrultusunda kullanılmak üzere geri dönüştürülebileceğine dikkat çekmektedir.

\section{Anahtar Kelimeler}

Çörek otu, kanser tedavisi, anti-anjiyojenik aktivite, korioallantoik membran testi.

Article History: Received: Aug 01, 2018; Revised: Sep 11, 2018; Accepted: Oct 03, 2018; Available Online: Nov 22, 2018.

DOI: 10.15671/HJBC.2018.268

Correspondence to: G. Tan, Department of Biology, Faculty of Science and Letters, Aksaray University, Aksaray, Turkey. 


\section{INTRODUCTION}

lant-based therapies, also called phytotherapy, have been in use since ancient times to relieve various diseases and disorders. The effects of natural compounds from plant extracts on diseases are still an intensive research area. In this area, which has gained great popularity nowadays, many plant extracts such as Nigella sativa L. (NS), Allium sativum, Curcuma longa, Cinnamomum zeylanicum, Syzygium aromaticum have been studied for their radical scavenging, antioxidant, antibacterial and anticancerogenic properties. Among medicinal plants, NS also known as 'black cumin or seed', is an annual flowering plant belonging to Ranunculaceae family which grows in the Middle East, Western Europe, Eastern and Central Asia [1]. NS is a species that draws attention with its therapeutic effect from medical perspective as well as being used as food and spice [2-5]. NS seed is added into tea, coffee or bread and used in the production of the canned goods. Its ground seeds can be mixed with honey or can be tossed in the salads. NS seed is used for many pharmaceutical purposes beyond its uses in food. NS has been used in the Middle and the Far East as a natural medicine for more than 2000 years [6]. NS falls into the category of herbs that are believed to possess a healing trait in Islamic communities (known as "Habbat al-Sauda", a remedy of every disease) [6-7]. NS, stated as the healing black seed in the Bible, is natively used plant, which pharaohs have declared to accompany eternity, Hippocrates and Dioscorides referred to NS as "Melanthion" in their drug recipes [6]. NS is called as "Kalonji" and "Karayal" in south and south-west Asia, as "Panacea' in old Latin and as "Hak Jung Chou" in China[6,8]. NS has been used as a folk medicine to treat intestinal, respiratory, gastric disorders, and to support immune and circulatory system as well as to maintain general well-being [7]. It is useful to regulate hypertension and to remedy bacterial diseases [9]. By mixing with other ingredients, it is also used to remove bad-breath odor and mouth-watering as well as being used for the treatment of diarrhea, dyspepsia, indigestion, burping[10]. Many phytochemical and bioactivity studies have been conducted on NS in addition to its remarkable traditional uses [9].The fixed oil in its seeds is particularly rich in polyunsaturated fatty acids, contributing to its antioxidant [1114], antiallergic [14-15], anti-inflammatory [14-16], immune modulating [14], antibacterial [17-19], antiviral [14], antitumoral [14,20-21], antidiabetic $[17,20,22]$, and hepatoprotective $[17,23]$ effects, as well as, contributing to its effects on the cardiovascular- hematological [20,24-25], and gastrointestinal systems [20].

The majority of NS-related studies in the literature have been conducted with the seeds, which have been obtained from the plant grown in the countries, where it is widely consumed or with the seed oil, which is easily available in the market. We have also noticed that the phytochemical studies have mainly focused on seeds and the other parts of the plant have not been investigated sufficiently yet. Nevertheless, it is possible to detect significant amounts of several important compounds like vitamins and proteins or their solid substances in the remaining seedcake (pulp) after the oil or extract production process. In fact, this pulp can be used in several products. They are used in the production of food additives for forage, herbal additives, soil fertilizers, cosmetics, pharmaceuticals and products in several other sectors. Therefore, unlike the studies in the literature, this study aims to investigate the phytochemical and biological activities of the extract, which is obtained from the pulp produced as a by-product of the oil production and to compare our results with the findings in the literature obtained from the seed extract and oil. This also enables to determine the potential of the pulp extract for the use as food and as medical substances. For this purpose, we have tried to investigate the radical scavenging and antioxidative capacity of the NS pulp extract and to demonstrate the relationship between the antioxidative effect and chemical compounds in the extract with fourier transform infrared (FTIR) and ultraviolet visible (UV-vis) spectroscopy measurements. In order to investigate the biological activities of the NS pulp extract, antiproliferation and antiangiogenesis tests have been performed. We have evaluated the antiproliferative effect of the NS pulp extract on both cancerous and non-cancerous cells in vitro in a comparative manner. In addition, the antiangiogenic properties of the pulp extract have been investigated on in ovo and ex ovo chick chorioallantoic membrane (CAM) model via vascular endothelial growth factor 
(VEGF)-stimulated vascularization. This study, which enables us to compare pulp extract of NS with its seed extract or seed oil, has a guiding role regarding the further studies on biological activity of other pulp extracts.

\section{MATERIALS and METHODS}

\section{Preparation of NS Pulp Extract}

NS extracts are generally used for their oil obtained by the cold press process of the seeds. At the end of this stage, the remaining pulp is discarded as waste. However, NS pulp also still contains considerable amounts of therapeutic components. In this study, the NS pulp was purchased a local herbal market. Sample was kept under sunshade for drying. The dried sample was grounded thoroughly to powder form. $50 \mathrm{~g}$ of powder was boiled into $1000 \mathrm{~mL}$ sterile distilled water for $5 \mathrm{~min}$ and then filtered through Whatman's No.1 filter paper. The extract was kept at $4{ }^{\circ} \mathrm{C}$ in sterile tubes covered by aluminium foil for further experiments. The samples were later evaporated under reduced pressure using a rotary evaporator (Labconco) for FTIR analysis.

\section{UV-vis Spectroscopy}

UV-Vis spectroscopic study was carried out using a Shimadzu UVmini-1240 UV-vis spectrophotometer. Samples were scanned at the wavelength range from 300 to $600 \mathrm{~nm}$.

\section{FTIR Instrumentation and Spectral Measurement}

FTIR experiment was carried out to determine the biomolecules present in the seed extract. FTIR spectra of NS pulp extract were recorded at room temperature $\left(\mathrm{ca} .22^{\circ} \mathrm{C}\right)$ using a Nicolet Avatar 380 spectrometer (Thermo Electron Inc., San Jose, CA) scanning over the frequency range of 4000 to $400 \mathrm{~cm}^{-1}$ at a resolution of $4 \mathrm{~cm}^{-1}$. The peaks obtained were analysed by using a standard IR spectra table.

\section{GC-MS Analysis of Extract}

Fatty acid composition of NS pulp extract was investigated by GC-MS analysis. NS pulp extract was dissolved in methanol, vortexed vigorously and then filtered. The fatty acid methyl esters were analyzed using an Agilent Technologies
5975C VL MSD with a triple-axis detector system and an Agilent 7890A GC system. The column was $5 \mathrm{MS}(60 \mathrm{~m} \times 0.25 \mathrm{~mm}$ ID, $0.25 \mathrm{~nm}$ film thickness). Carrier gas was helium ( $1.5 \mathrm{~mL} / \mathrm{min})$. GC oven temperature was programmed as $5 \mathrm{~min}$ at $50^{\circ} \mathrm{C}$ initially, then heated up to $220^{\circ} \mathrm{C}$ at the rate of $2^{\circ} \mathrm{C}$ min (total $90 \mathrm{~min}$ ). One microliter sample was injected into the system. Injection mode: was adjusted to split mode (20:1). Injector temperature was set at $250^{\circ} \mathrm{C}$. Transfer line temperature was set at $280^{\circ} \mathrm{C}$. Mass spectrum was operated at 70 eV. Mass range was 70 to $250 \mathrm{~m} / \mathrm{z}$. GC Detector or flame ionization detection (FID) was set at $210^{\circ} \mathrm{C}$. In order to obtain the same elution order with GCMS, the column outlet was split into two, one for FID and the other for MS detector.

\section{pH Measurement}

Since the acid base balance is extremely important, the $\mathrm{pH}$ of the materials to be used must be determined. Prepared extract $\mathrm{pH}$ was measured with ISOLAB magnetic mixer and $\mathrm{pH} /$ ORP / temperature meter.

\section{Trolox Equivalent Antioxidant Capacity (TEAC)}

In accordance with Marinova and Batchvarov [26]'s methods, Trolox standard was prepared at concentrations of $0.5 \mathrm{ppm}, 1 \mathrm{ppm}, 1.5 \mathrm{ppm}, 2 \mathrm{ppm}$, $2.5 \mathrm{ppm}$ and plotted against \% reduction values. Subsequently, \% reduction value of sample was determined as the result of absorbance readings and then the trolox concentration value over the graph was calculated. For the spectrophotometric assay, the absorbance was determined at $517 \mathrm{~nm}$.

\section{Radical Scavenging Activity by DPPH Assay}

This assay was carried out as described by Kirby and Schmidt [27], Sarikurkcu, et al. [2829] with some alterations suggested by Sanda, et al. [30]. $0.5 \mathrm{ml}$ of the methanolic sample extracts and commercial antioxidant butylated hydroxytoluene (BHT) in the methanol was mixed with $3 \mathrm{~mL} 6.10^{-5} \mathrm{M}$ of a methanol solution of 2 , 2-Diphenyl-1-picrylhydrazyl (DPPH). Then the mixture was incubated for $30 \mathrm{~min}$ in the dark at room temperature. Following to incubation period, the absorbance of mixture was measured at 517 $\mathrm{nm}$ with a spectrophotometer (Beckman Coulter DU 730 UV-Vis Spectrophotometer). Inhibition of 
free radical DPPH in percent (I \%) was calculated according to equation given below.

$$
\mathrm{I}(\%)=100 \times\left(\mathrm{A}_{\text {blank }}-\mathrm{A}_{\text {sample }}\right) / \mathrm{A}_{\text {blank }} \quad \text { (Equation 1) }
$$

Where $A_{\text {blank }}$ indicates absorbance of the control, whereas $A_{\text {sample }}$ represents absorbance of sample. BHT was considered as the standard antioxidant used for positive control. Results were expressed by calculating $I C_{50}$ values obtained from regression curve. The lower the $\mathrm{IC}_{50}$ values point toward the higher antioxidant activity.

\section{Cell Lines}

Mouse fibroblastic (L929) and lung adenocarcinoma (A549) cell lines were cultured and grown in Dulbecco's Modified Eagle's Medium (DMEM) (Gibco, USA) supplemented by $10 \%$ fetal bovine serum (FBS) (Gibco, USA) and 1\% penicillin-streptomycin (Sigma-Aldrich, Germany). The cells were maintained at $37^{\circ} \mathrm{C}$ under a humidified atmosphere with $5 \% \mathrm{CO}_{2}$. The medium was refreshed two or three times each week.

\section{MTT Assay}

The cytotoxic effect and the antiproliferative activity of NS pulp extract were measured in vitro on A549 and L929 using with the MTT [3-(4,5dimethylthiazol-2-yl)-2,5-diphenyltetrazolium bromide] assay described by Mosmann [31]. Cells $\left(5 \times 10^{3}\right.$ cells/well) were separately seeded onto 96-well microplates and incubated at $37^{\circ} \mathrm{C}$ in a humidified $5 \% \mathrm{CO}_{2}$ atmosphere. On the second day, $200 \mu \mathrm{L}$ fresh medium containing with different concentrations $(0.1-1000 \mu \mathrm{g} / \mathrm{mL})$ of pulp extract was added. The samples were then incubated for an additional 24h. After $24 \mathrm{~h}$ of incubation, the medium was removed and $100 \mu \mathrm{L}$ of serum-free medium containing $5 \mathrm{mg} / \mathrm{mL}$ of MTT was added to each well. MTT was converted by intact mitochondrial reductase and precipitated as blue crystals during a $4 \mathrm{~h}$ contact period. The medium was then removed carefully and $100 \mu \mathrm{L}$ of isopropyl alcohol was added to each well to solubilize formazan. The plates were agitated for 10 min and absorbance was measured with a platereading spectrophotometer at $570 \mathrm{~nm}$ (Biochrom EZ Read 400). Absorbance of the treated cells was compared with that of the control, and cells exposed only to normal medium were considered
$100 \%$ viable. The percentage of cell viability was calculated using the following formula:

Cell Viability $(\%)=($ Optical Density of Treated Cells $/$ Optical Density of Control Cells)x100 (Equation 2)

L929 fibroblastic cell line from mouse, which was not tumorigenic, served as controls in order to analyse toxicity of NS pulp extract on normal cells.

\section{CAM Assay}

The Atabey type fertilized chicken eggs were incubated at $37^{\circ} \mathrm{C}$, at constant humidity. In order to reveal the developing vascularized chorioallantois, on day 3 of incubation, the eggs were removed from the incubator and cleaned with $70 \%$ alcohol and a hole is drilled through the pointed pole of the shell. In order to initiate a pathological vascularization condition, $10 \mathrm{ng} /$ $\mathrm{mL}$ VEGF $_{165}$ was injected with an insulin syringe on the embryos. After $24 \mathrm{~h}, 100 \mu \mathrm{L}$ of NS pulp extract at different concentrations $(10,100$, and $500 \mu \mathrm{g} / \mathrm{mL}$ ) was applied via micropipettes. Then, the holes were covered with cellophane tape. After one day of incubation, the top cover of the eggs was broken. The CAM arterious branches in each treatment group were photographed using Leica stereomicroscope (Leica M205C) fitted with a camera system (Leica DCF295, Heerbrug, Switzerland) and counted by Wimasis online analysis tool (Wimasis $\mathrm{GmbH}$, Germany). The antiproliferative effect of the NS pulp extract was determined as relative numbers of arteriosus branches. The assay was performed three times to ensure reproducibility.

\section{Statistical Analysis}

All experiments were performed in triplicate $(n=3)$. The variance analysis was performed to compare means with $p<0.05$ and $p<0.01$ indicating statistical significance. All statistical analyses were performed using IBM SPSS (ver. 21).

\section{RESULTS and DISCUSSION}

In the present study, the UV-vis absorption spectrum recorded from NS pulp extract showed an absorption peak at $290 \mathrm{~nm}$ attributed to the surface plasmon resonance band (SPR) (Figure 1). 


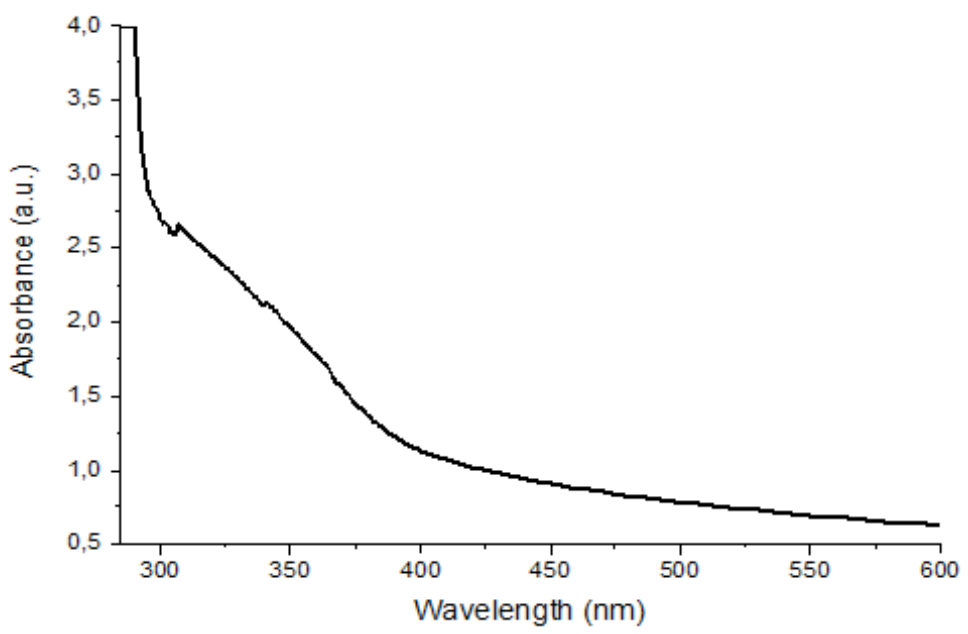

Figure 1. UV-Vis scan of Nigella sativa pulp extract. The absorbance measurements were recorded at wavelengths between 300 and $600 \mathrm{~nm}$.

This result is in agreement with the previous findings. Velho-Pereira, et al. [32] reported that the macerated extract from the aqueous seed of NS showed the absorbance peak at $287 \mathrm{~nm}$. We also observed the peaks in the UV range corresponding to 300 and $350 \mathrm{~nm}$, which may be attributed to the presence of proteins in the solution released by the NS pulp extract. The wavelengths of absorption peaks can be correlated with the types of bonds in a given molecule and are valuable in determining the functional groups present within a molecule.
Thanks to providing information about fingerprint characteristics of samples and being broadly applicable to the samples, FTIR has a prominent place in pharmaceutical analysis. FTIR measurement was carried out to identify possible biomolecules or bio functional groups of NS pulp extract.

Figure 2 illustrates the infrared spectrum of NS pulp extract in the region from 4000 to $500 \mathrm{~cm}^{-1}$. The $\mathrm{OH}$ stretching in Phenol group was observed at $3280.33 \mathrm{~cm}^{-1}$. The $\mathrm{CH}_{3}$ and $\mathrm{CH}_{2}\left(\mathrm{C}-\mathrm{H}\right.$ in $-\mathrm{CH}_{3}$ and $\left.-\mathrm{CH}_{2}\right)$

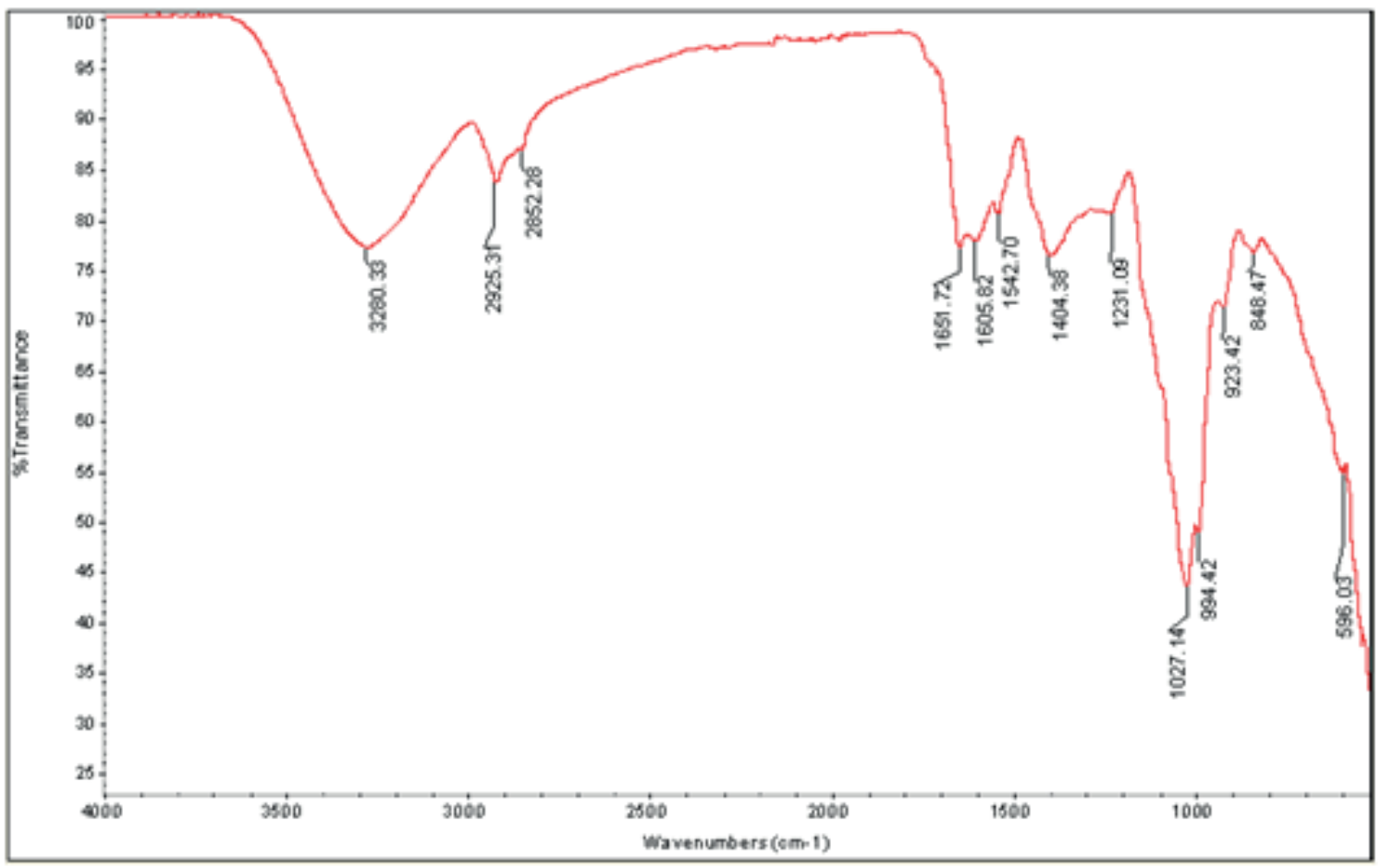

Figure 2. Representative FTIR spectra from dried Nigella sativa pulp extract. All wavenumber values are in $\mathrm{cm}^{-1}$. 
Table 1. FTIR spectrum of the Nigella sativa pulp extract depicts the related functional groups of transmittance bands of the corresponding wavelengths.

\begin{tabular}{|c|c|c|c|}
\hline $\begin{array}{l}\text { Wavelength range } \\
\qquad\left(\mathrm{cm}^{-1}\right)\end{array}$ & NS pulp extract & Assignment & Possible Compounds \\
\hline $3500-3000$ & 3280.33 & Bonded -OH groups & Alcohols, Phenols, Acids \\
\hline $2900-2800$ & $2925.31,2852.28$ & $\begin{array}{l}\mathrm{CH} \text { stretching vibration (aliphatic) } \\
\qquad\left(\mathrm{CH}_{3} \text { and } \mathrm{CH}_{2}\right)\end{array}$ & Alkanes \\
\hline $1670-1640$ & 1651.72 & $\mathrm{C}=\mathrm{O}$ carbonyl groups & Alkanes \\
\hline $1600-1300$ & $\begin{array}{c}1605.82,1542.70 \\
1404.38\end{array}$ & $\begin{array}{c}\mathrm{C}=\mathrm{C} \text { stretching, carboxylic groups } \\
\text { and } \mathrm{N}-\mathrm{H} \text { vibrations }\end{array}$ & Aromatics, Amines \\
\hline $1300-1200$ & 1231.09 & Carbonyl group & Ester \\
\hline $1150-950$ & $\begin{array}{c}1027.14,994.42,923.42 \\
848.47\end{array}$ & $\mathrm{C}-\mathrm{H}$ bending and $\mathrm{C}-\mathrm{N}$ stretching & Aliphatic amines, Alkenes \\
\hline $800-500$ & 596.03 & C-X stretching & Alkyl halides \\
\hline
\end{tabular}

asymmetric stretching vibrations were found in the region of 2925 and $2852 \mathrm{~cm}^{-1}$, respectively [33-35]. These characteristic bands indicate the presence of alkanes. The $\mathrm{C}=\mathrm{O}$ (carbonyl) stretching band was observed at $1651.72 \mathrm{~cm}^{-1}$. The $\mathrm{C}=\mathrm{C}$ stretching band at $1600-1350 \mathrm{~cm}^{-1}$ could be attributed to the presence of aromatic compounds like freely water-soluble flavonoids in NS pulp extract. The bands between the wavenumbers of 1500 to $500 \mathrm{~cm}^{-1}$ (fingerprint regions) of the spectrum, for the control reflected the biochemical compositions, especially the moieties of carbohydrate, lipid, protein and polyphenols in NS pulp extract. The FTIR spectroscopy results showed that phenolic and aromatic compounds were present in the NS. which are consistent with the findings of the phytochemical analysis (Table 1). Also, $\mathrm{pH}$ value of the sample is measured as 6.27.

GC-MS results showed that the NS pulp extract contains a largely higher proportion of unsaturated fatty acids as compared to saturated oils. The major fatty acids of the pulp are linoleic acid methyl ester or methyl linoleate $(28,2 \%)$, linolelaidic acid (17,3\%), 1-hexadecyne (17,3\%), linoleic acid (16,3\%), oleic acid $(11,4 \%)$, myristic acid $(6 \%)$, palmitic acid $(1,5 \%)$ margaric acid (heptadecanoic acid) (1,2\%). GC-MS chromatogram, area \% and retention times of the compounds identified from pulp extract are given in Figure 3 and Table 2, respectively.

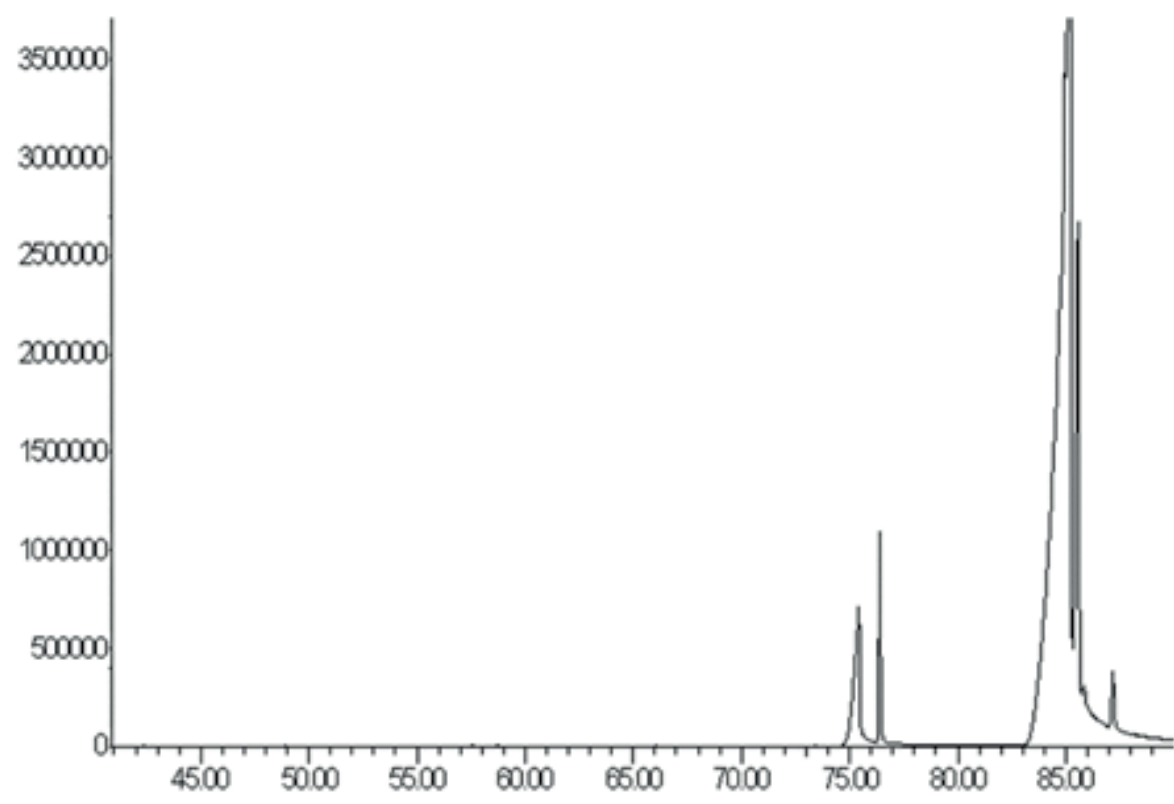

Figure 3. GC-MS chromatogram of main compounds in Nigella sativa pulp extract. 
Table 2. The main compounds determined by GC-MS in Nigella sativa pulp extract.

\begin{tabular}{cccc}
\hline Pk\# & Compound name & \%area & Retention Time \\
\hline 1 & Myristic Acid & 5.601 & 75.434 \\
\hline 2 & Palmitic Acid & 1.477 & 76.397 \\
\hline 3 & Margaric Acid & 1.213 & 76.406 \\
\hline 4 & Linoleic Acid & 16.292 & 84.428 \\
\hline 5 & 1-Hexadecyne & 17.335 & 84.766 \\
\hline 6 & Linolelaidic Acid & 17.337 & 84.985 \\
\hline 7 & Methyl Linolelaidate & 28.218 & 85.186 \\
\hline 8 & Oleic acid & 11.431 & 85.559 \\
\hline 9 & Stearic Acid & 0.630 & 87.178 \\
\hline 10 & Myristic Acid & 0.425 & 87.195
\end{tabular}

Scavenging free radicals resulting from aerobic cellular reactions might reduce the oxidative stress level of cells, and so prevent the oxidation of biomolecules, which causes pathological conditions for many diseases such as cancer, cardiovascular disorders, neurodegenerative diseases and so on [36-39]. Total antioxidant activity analyses were determined according to the DPPH radical scavenging method. DPPH has been broadly accepted free radical to evaluate radicalscavenging activities of plant extracts [40-41]. To evaluate antioxidant capacity of NS pulp extract, its Trolox equivalents and $\mathrm{IC}_{50}$ values to scavenge DPPH were determined. TEAC values of pulp extract were calculated using a Trolox standard curve and were expressed as Trolox equivalents (mg TE /100 $\mathrm{mL}$ ). TEAC values of pulp extracts were calculated as 8,75 $\pm 0,06 \mathrm{TE} \mathrm{mg} / 100 \mathrm{~mL}$.

The antiradical activity of NS pulp extract and synthetic antioxidant BHT were measured by using DPPH based on their $\mathrm{IC}_{50}$ values, described as the amount of the antioxidant needed to inhibit $50 \%$ of DPPH existing in the test material. The assessment of radical-scavenging activity showed that NS pulp extract was able to eliminate free radicals.

The radical scavenging effect of NS pulp extract $\left(I C_{50}=153.61 \pm 9.78 \mu \mathrm{g} / \mathrm{ml}\right)$ was found to be 4.5-fold less potent than the standard $\mathrm{BHT}$ $\left(\mathrm{IC}_{50}=34.06 \pm 0.38 \mu \mathrm{g} / \mathrm{ml}\right.$ ) (Table 3). However, all these results also indicated that NS pulp extract still preserves its antioxidant capacity and can be potentially used to scavenge free radicals. This can be considered to relate to the phenolic components particularly in the structure of pulp extract. The presence of flavonoids and some particular alkenes might also has an effect on antioxidant activity [42]. Sangeetha, et al. [42] reported that NS exhibited higher antioxidant activity than Eugenia jambolana, which contains quite similar compounds to NS, except some alkenes. Table 4 also shows that scavenging activity of pulp extract on DPPH enhanced linearly with increasing concentration.

In literature, NS shoots and roots have been reported to display 17 -fold and 28 -fold lower radical scavenging effect than that of $\mathrm{BHT}$, respectively [43]. This suggests that the NS pulp extract has a higher antioxidant capacity when compared to its root and shoots. Singh, et al. [44] concluded that the essential oil and acetone extract of NS provide moderate and high antioxidant activity compared to synthetic antioxidants such as BHT and BHA. In another study, the seed extract of NS from India exhibited relatively lower scavenging effect with a $\mathrm{IC}_{50}$ value of $1240 \mu \mathrm{g} \mathrm{ml} \mathrm{l}^{-1}$ compared to our pulp extract [45]. Undoubtedly, one reason for these

Table 3. $I C_{50}$ values of sample (Nigella sativa pulp extract) and standard (BHT).

\begin{tabular}{cc}
\hline & $\mathrm{IC}_{50}(\mu \mathrm{g} / \mathrm{ml})^{*}$ \\
\hline Sample & $153.61 \pm 9.78$ \\
\hline BHT & $34.06 \pm 0.38$
\end{tabular}

*Mean of three parallel analysis \pm S.D. 
Table 4. DPPH scavenging activity of Nigella sativa pulp extract

\begin{tabular}{cc}
\hline Concentration $(\mu \mathrm{g} / \mathrm{ml})$ & Inhibiton $(\%)^{*}$ \\
\hline 1000 & $71.57 \pm 0.36$ \\
\hline 500 & $60.06 \pm 1.04$ \\
\hline 250 & $51.23 \pm 1.32$ \\
\hline 125 & $49.71 \pm 0.18$ \\
\hline
\end{tabular}

"Mean of three parallel analysis \pm S.D.

findings relates to the geographical area where NS is grown-in [46]. For this reason, it should be noted that pulp extracts might have different free radical scavenging effects depending on the region where NS is grown.

Kadam and Lele [47] revealed the characteristic LC-MS profile of NS pulp extracts and founded many phenolic contents such as Kaempferol, p-coumaroyl acid derivative and Thymol-O-sophoroside. The authors also reported that polyphenols extracted in NS pulp exhibited significant antioxidant and anti-inflammatory activity [47]. Similarly, Mariod, et al. [48] investigated antioxidant activities of crude methanolic extract and its different fractions with ethyl acetate, hexane and water respectively of NS pulp extract by using different techniques including $\mathrm{DPPH}, \quad \beta$-carotene bleaching and inhibition of corn oil oxidation assays. The results showed that NS pulp extract and their fractions successfully inhibited corn oil oxidation thanks to their phenolic contents. In another study, due to its rich polyphenolic compounds and antioxidant properties thereof, NS pulp extract was mixed with chitosan solutions at different $\mathrm{v} / \mathrm{v}$ ratios to form films[49]. The polyphenolic extract of NS pulp contributed to substantial alterations in functional properties of chitosan films including water vapor permeability, crystallinity, thermal stability, tensile strength and elongation, antioxidant capacity etc. Thus, it was reported that these films obtained from NS pulp remaining after oil extraction can be used in food packaging or preservation and nutraceutical applications. In a study on calves, it was observed that the use of NS pulp as an additive in animal feeds resulted in an increase in the number of leukocytes and accordingly immune system-enhancement against various parasites [50]. Therefore, it is suggested that the use of NS pulp in animal feeds to strengthen the immune system and reduce the risk of diseases.
This relatively high antioxidant capacity suggests that NS pulp extracts, which emerged as a waste product, might be potentially useful as plant fertilizer and animal food as well as food preservation component. NS pulp extract can also be used with different antioxidant components. As it is known, the vast majority of natural antioxidant constituents affect each other and synergistically create a broad range of antioxidative activities against free radicals [51]. Briefly, all these conclusions suggest us to consider about the use of pulp extract as a natural antioxidant.

Despite the increasing number of studies regarding the cellular aerobic conditions in recent years, the effect of oxidative stress on intracellular processes and structures has not yet been understood in all aspects. Recent studies have shown the importance of the balance between aerobes and anti-antioxidants. The modulation of aerobes' activities via antioxidants especially the balance between them enables reactive oxygen species (ROS) to undertake useful functions while preventing harmful effects of oxidative stress [52]. Amount of antioxidant agents used may impair their positive effects on the cell signaling [53]. It also should be noted that the excessive removal of ROS from the biological systems might be harmful for health. The effect observed may vary depending on the applied dose [54]. On the other hand, cell medium conditions might lead to enhance oxidative stress level on the cells, resulting in an artificial effect on the role of reactive oxygen species as well as antioxidants applied on the cultured cells. This leads us to act with suspicion towards whether some redox active ingredients (especially flavonoids and polyphenols) may exhibit antioxidant properties under in vivo conditions [52]. In literature, more studies comparing the effects of antioxidants on both in vitro and in vivo conditions are highly needed to capture the in-depth understanding of 
the potential of one compound over another[55]. In addition, the use of different antioxidant assays is also highly critical [56]. This study contributes to the existing literature, thanks to being performed both in vitro and in vivo conditions as well as utilizing different antioxidant analysis methods.

Cancer is a disease that occurs resulting from continuous and uncontrolled proliferation of cells. Several in vivo and in vitro studies have demonstrated the anticancer effects of NS seeds and their active ingredients. In order to test antimetastatic properties of NS pulp extract, the effects of its different concentrations were studied on A549 and L929 cells for $24 \mathrm{~h}$. When we looked at the effects on cell viability, there was no significant decrease in $\mathbf{2 9 2 9}$ mouse fibroblast cells after $24 \mathrm{~h}$ of incubation period, whereas a decrease in cell viability was observed at $500 \mu \mathrm{g} / \mathrm{mL}$ in $\mathrm{A} 549$ adenocarcinoma cells, an extremely aggressive cancer cell line. Cell viability decreased by $65 \%$ on A549 cells at $1000 \mu \mathrm{g} / \mathrm{mL}$ (Figure 4).

Researches have recently shown that the active ingredients of NS seed like Thymoquinone in particular, has an inhibitory effect on the proliferation of cells in many types of cancer including breast and ovarian adenocarcinoma [57], colorectal cancer [58], neoplastic keratinocytes [59], human osteosarcoma [60], fibro sarcoma [61], lung carcinoma [62-63], prostate cancer [64]. Thymoquinone and dithymyquinone can inhibit cancer cell growth by triggering apoptosis while the cells are in G1 phase. The arrest of cell growth is achieved by increasing gene expression and protein expression of $\mathrm{p} 53$ and inhibiting the antiapoptotic $\mathrm{Bcl}-2$ protein [58]. Briefly, thymoquinone is mainly considered to be responsible for the anticancer and antimetastatic activities of NS [65-68]. However, our GC-MS results revealed that thymoquinone, which is the main constituent of NS extracts and their volatile oils [69], was not found in NS pulp. Nevertheless, although NS related studies up to date have not focused on as much as thymoquinone, according to our results poly- and monounsaturated fatty acids, present in NS pulp extract have also anti-proliferative effects against cancer cells. The complexes formed with unsaturated fatty acids such as linoleic acid and oleic acid, were reported to cause cytotoxicity against different cancer types, induce apoptosis as well as restrict tumor growth and progression in vivo [70-73]. In addition, highunsaturated fatty acid contents in NS pulp can be useful contribute considerable resistance to oxidative reactions on food storage in particular [74].

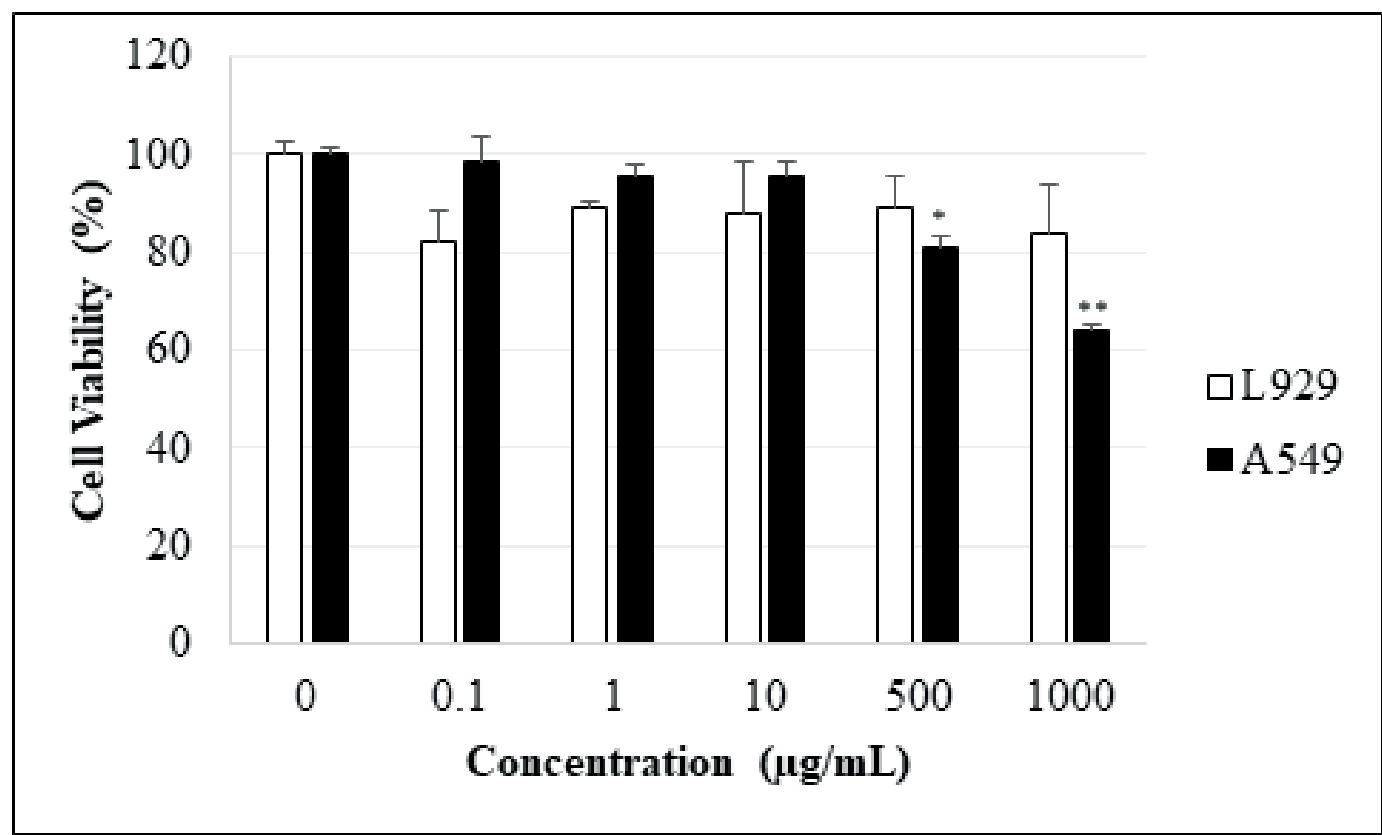

Figure 4. The effect of Nigella sativa pulp extract on both $L 929$ and A549 cell viability. Cells were treated with the extract for $24 \mathrm{~h}$. Values are presented as mean \pm SEM of three independent experiments. $\left({ }^{*} p<0.05,{ }^{* *} p<0.01\right.$ vs Control). 
There are many studies in the literature on NS extract. However, they are mostly in vitro studies and the number of in vivo studies is rather limited. CAM assay is used as an in vivo model in many angiogenesis studies. In our study, NS pulp extract with different concentrations was tested on in ovo CAM model. During the analysis, total vessel density, total vessels network length, total branching point and total segment were investigated as indicators of the angiogenesis process. The data were generated by analysing three stereomicroscope images for each group with an online CAM analysis software (Figure 5). In the analysis process, especially newly formed vessels were identified or marked and then measured. The analysed form of CAM images in Figure $5 \mathrm{~A}$ can be seen in Figure 6 . In addition, the effect of the pulp extract on the VEGF-stimulated embryonal development was evaluated with an ex ovo model to support the results of the in ovo testing.

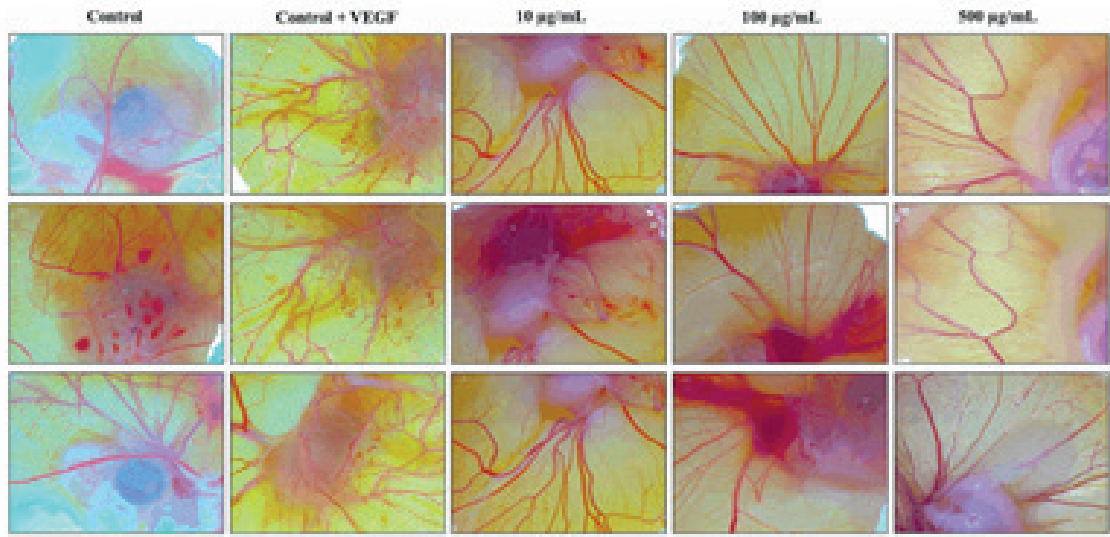

(A)
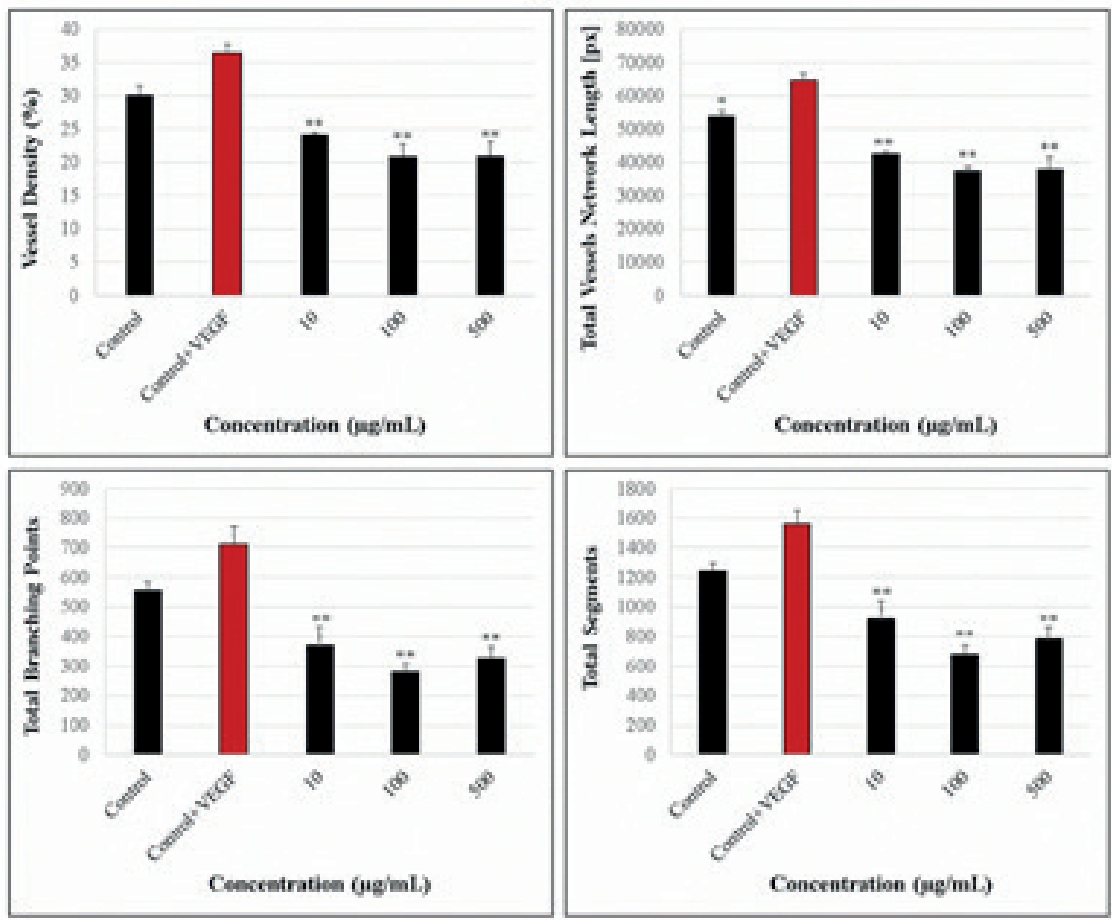

(B)

Figure 5. A.) Stereomicroscope images of VEGF-stimulated CAM vascularization treated with Nigella sativa pulp extract at different concentrations (10,100 and $500 \mu \mathrm{g} / \mathrm{mL}$ ). Scale bars, $1 \mathrm{~mm}$. All groups except control were pre-incubated with $10 \mathrm{ng} / \mathrm{mL}$ VEGF for $24 \mathrm{~h}$. B.) The effects of Nigella sativa pulp extracts on VEGF-stimulated angiogenesis including vessel density (\%), total vessels network length ( $\mathrm{px}$ ), total braching points (number) and total vessel segments (number) obtained from three stereomicroscope CAM images of each group. All treatment groups were pre-treated with $10 \mathrm{ng} / \mathrm{mL} \mathrm{VEGF}_{165}$ for $24 \mathrm{~h}$. All comparisons were made with respect to the $10 \mathrm{ng} / \mathrm{mL}$ VEGF group considered as the positive control. The values represent as means and standard error of triplicate experiments $\left({ }^{*} p<0.05,{ }^{* *} p<0.01\right.$ vs Control+VEGF). 

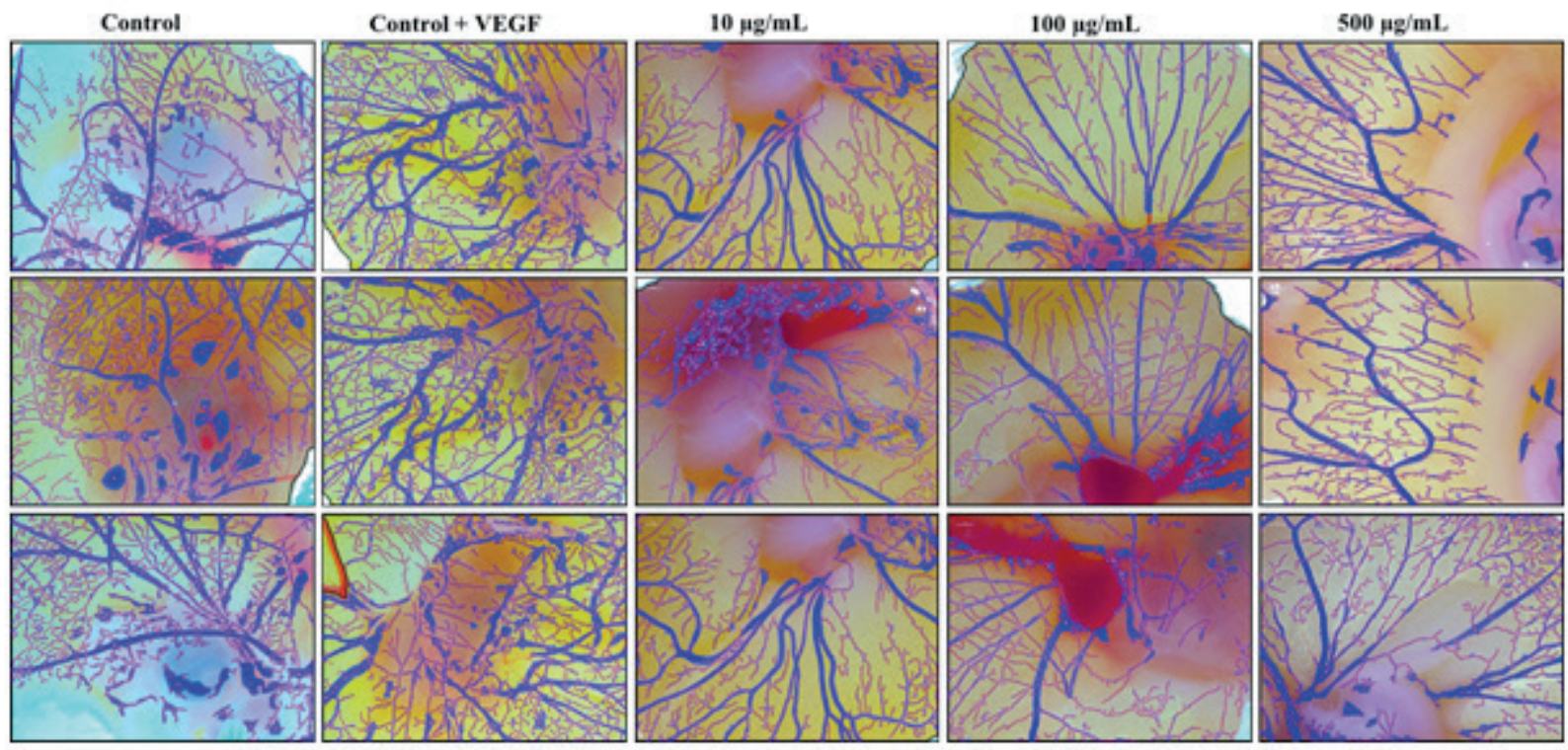

Figure 6. The stereomicroscope CAM images for each group after analysis.

The positive control group treated with $10 \mathrm{ng} /$ $\mathrm{mL}$ VEGF $_{165}$ showed an increase in all angiogenesis indicators measured during the study compared to non-treated control group. After the treatment of $10 \mathrm{ng} / \mathrm{mL} \mathrm{VEGF}_{165}$ in all groups except the control group, NS pulp extract at different concentrations $(10,100,500 \mu \mathrm{g} / \mathrm{mL})$ was applied to the CAM model. When the total vascular density was taken into account, the group treated with $10 \mu \mathrm{g} / \mathrm{mL}$ NS pulp showed a decrease of approx. 33\%, whereas the concentrations of 100 and $500 \mu \mathrm{g} / \mathrm{mL}$ induced a decrease of approx. 45\%. Total vessel length decreased in all groups.

As an interesting result, total branching points and total segments were lower in the groups treated with $100 \mu \mathrm{g} / \mathrm{mL}$ than the groups treated with 500 $\mu \mathrm{g} / \mathrm{mL}$. In this study, it was shown in the CAM model that the NS pulp extract inhibited dose-dependently the formation of the blood vessel formation. For a more detailed investigation of the suppressive effect on the VEGF-stimulated angiogenesis of the NS pulp extract, we investigated the embryonic development
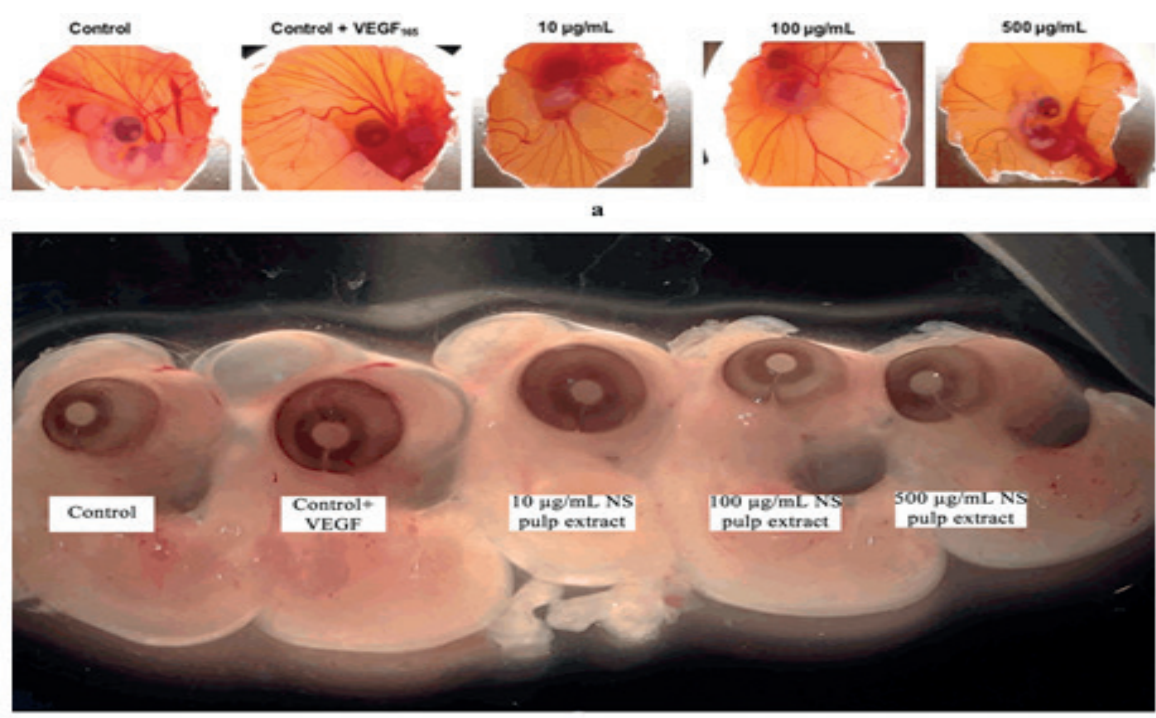

Figure 7. The restrictive effect of Nigella sativa pulp extract on VEGF-stimulated embryonic growth both in ovo (a) and ex ovo (b). All groups except control were pre-treated for $24 \mathrm{~h}$ with $10 \mathrm{ng} / \mathrm{mL} \mathrm{VEGF}_{165}$. 
of the fertile chick eggs exposed to the pulp extract. The results displayed that the NS pulp inhibited the VEGF-stimulated embryonic development under both in ovo and ex ovo conditions (Figure 7).

One of the underlying factors of NS's anticancer properties is its ability to inhibit some angiogenesis and metastasis-inducing cytokines. All these results showed that NS pulp extract might be used in diseases like cancer, which progress with pathological angiogenesis thanks to its antimetastatic and antiangiogenic properties and it might provide positive results in the prevention and treatment of many diseases thanks to its antioxidative activity, which enables the removal of the free radical compounds from the cells as well.

In the literature, all studies on NS have been carried out mainly with seed extract or seed oil. There are only a few studies on biological activity of NS pulp extract directly. This aspect, which is one of the distinguishing features of our study, will make an important contribution to the usage of a waste material and, thus pave the way for an environmentally friendly approach. This study shows that the pulp extract contains active constituents of NS even small quantities. It is desirable to show that the biological effects of the pulp can produce such remarkable results that it can be used for many different purposes in medicine, animal husbandry and so on, rather than decapitating it. The extract obtained from the pulp might be evaluated as a source for the phytotherapeutic activity studies in the future.

\section{Acknowledgments}

The author would like to thank Assoc. Prof. H. M. Aydin, who has provided laboratory facilities for cell culture studies, and PhD. student A Tevlek for his technical assistance. In addition, the author would like to thank Assoc. Prof. Y. S. Çakmak, who shares all the knowledge of DPPH activity.

Disclosure statement (Conflict of interest) Author(s) declare that there are no conflicts of interest associated with this publication and there has been no significant financial support for this work that could have influenced its outcome.

\section{References}

1. E. Daukšas, P.R. Venskutonis, B. Sivik, Comparison of oil from nigella damascena seed recovered by pressing, conventional solvent extraction and carbon dioxide extraction, J. Food Sci., 67 (2002) 1021-1024.

2. W.C. Evans, Trease and Evans' Pharmacognosy, 16th ed., Saunders Ltd., Edinburgh, 2009.

3. M. Tanker, N. Tanker, Farmakognazi, Ankara University Faculty of Pharmacy Press No: 58, Ankara, Turkey, 1985.

4. M. Tanker, N. Tanker, Farmakognazi, Ankara University Faculty of Pharmacy Press No: 65, Ankara, Turkey, 1990.

5. N. Tanker, M. Koyuncu, M. Coşkun, Farmasötik Botanik, Ankara Üniversitesi Eczacılık Fakültesi Yayınları, Ankara, Turkey, 2007.

6. S. Padhye, S. Banerjee, A. Ahmad, R. Mohammad, F.H. Sarkar, From here to eternity - the secret of Pharaohs: Therapeutic potential of black cumin seeds and beyond, Cancer Ther., 6 (2008) 495-510.

7. A. Ahmad, A. Husain, M. Mujeeb, S.A. Khan, A.K. Najmi, N.A. Siddique, Z.A. Damanhouri, F. Anwar, A review on therapeutic potential of Nigella sativa: A miracle herb, Asian Pac. J. Trop. Biomed., 3 (2013) 337-352.

8. B.B. Aggarwal, A.B. Kunnumakkara, K.B. Harikumar, S.T. Tharakan, B. Sung, P. Anand, Potential of spicederived phytochemicals for cancer prevention, Planta Med., 74 (2008) 1560-1569.

9. M. Tariq, Nigella sativa Seeds: Folklore Treatment in Modern Day Medicine, Saudi J. Gastroenterol., 14 (2008) 105-106.

10. A.H. Gilani, Q. Jabeen, M.A.U. Khan, A review of medicinal uses and pharmacological activities of Nigella sativa, Pakistan J. Biolog. Sci., 7 (2004) 441451.

11. M. Burits, F. Bucar, Antioxidant activity of Nigella sativa essential oil, Phytother. Res., 14 (2000) 323328.

12. M. Türkdoğan, Z. Ağaoğlu, Z. Yener, R. Sekeroğlu, H. Akkan, M. Avci, The role of antioxidant vitamins (C and $\mathrm{E}$ ), selenium and Nigella sativa in the prevention of liver fibrosis and cirrhosis in rabbits: new hopes, Dtsch. Tierarztl. Wochenschr., 108 (2001) 71-73.

13. M.F. Ramadan, L.W. Kroh, J.-T. Mörsel, Radical scavenging activity of black cumin (Nigella sativa L.), coriander (Coriandrum sativum L.), and niger (Guizotia abyssinica Cass.) crude seed oils and oil fractions, J. Agric. Food Chem., 51 (2003) 6961-6969.

14. M.L. Salem, Immunomodulatory and therapeutic properties of the Nigella sativa L. seed, Int. Immunopharmacol., 5 (2005) 1749-1770.

15. U. Kalus, A. Pruss, J. Bystron, M. Jurecka, A. Smekalova, J.J. Lichius, H. Kiesewetter, Effect of Nigella sativa (black seed) on subjective feeling in patients with allergic diseases, Phytother. Res., 17 (2003) 1209-1214.

16. P.J. Houghton, R. Zarka, B. de las Heras, J.R.S. Hoult, Fixed oil of Nigella sativa and derived thymoquinone inhibit eicosanoid generation in leukocytes and membrane lipid peroxidation, Planta Med., 61 (1995) 33-36 
17. M.A. Khan, Chemical composition and medicinal properties of Nigella sativa Linn, Inflammopharmacology, 7 (1999) 15-35.

18. M. Hanafy, M. Hatem, Studies on the antimicrobial activity of Nigella sativa seed (black cumin), J. Ethnopharmacol., 34 (1991) 275-278.

19. E.M. Aboul, N. El-Shaer, N. Ghanem, Antimicrobial evaluation and chromatographic analysis of some essential and fixed oils, Pharmazie, 51 (1996) 993-994.

20. B.H. Ali, G. Blunden, Pharmacological and toxicological properties of Nigella sativa, Phytother. Res., 17 (2003) 299-305.

21. S.A.A. Linjawi, W.K.B. Khalil, M.M. Hassanane, E.S Ahmed, Evaluation of the protective effect of Nigella sativa extract and its primary active component thymoquinone against DMBA-induced breast cancer in female rats, Arch. Med. Sci. 11 (2015) 220-229.

22. M.F. Ramadan, Nutritional value, functional properties and nutraceutical applications of black cumin (Nigella sativa L.): an overview, Int. J. Food Sci. Technol., 42 (2007) 1208-1218.

23. M. El-Dakhakhny, N.I. Mady, M.A. Halim, Nigella sativa L. oil protects against induced hepatotoxicity and improves serum lipid profile in rats, Arzneimittelforschung, 50 (2000) 832-836.

24. A. Zaoui, Y. Cherrah, K. Alaoui, N. Mahassine, H. Amarouch, M. Hassar, Effects of Nigella sativa fixed oil on blood homeostasis in rat, J. Ethnopharmacol. 79 (2002) 23-26.

25. Z. Ibraheim, Effect of Nigella sativa seeds and total oil on some blood parameters in female volunteers Saudi Pharm. J., 10 (2002) 54-59.

26. G. Marinova, V. Batchvarov, Evaluation of the methods for determination of the free radical scavenging activity by DPPH, Bulg. J. Agric. Sci., 17 (2011) 11-24.

27. A.J. Kirby, R.J. Schmidt, The antioxidant activity of Chinese herbs for eczema and of placebo herbs - I, J. Ethnopharmacol., 56 (1997) 103-108.

28. C. Sarikurkcu, B. Tepe, D. Daferera, M. Polissiou, M. Harmandar, Studies on the antioxidant activity of the essential oil and methanol extract of Marrubium globosum subsp. globosum (lamiaceae) by three different chemical assays, Bioresour. Technol., 99 (2008) 4239-4246.

29. C. Sarikurkcu, K. Arisoy, B. Tepe, A. Cakir, G. Abali, E. Mete, Studies on the antioxidant activity of essential oil and different solvent extracts of Vitex agnus castus L. fruits from Turkey, Food Chem. Toxicol., 47 (2009) 2479-2483.

30. M.A. Sanda, G. Zengin, A. Aktümsek, Y.S. Çakmak, Evaluation of antioxidant potential of two Daphne species (D. gnidioides and D. pontica) from Turkey, Emirates J. Food Agricult., 27 (2015) 488-494.

31. T. Mosmann, Rapid colorimetric assay for cellular growth and survival: Application to proliferation and cytotoxicity assays, J. Immunol. Method., 65 (1983) 55-63.

32. R. Velho-Pereira, A. Kumar, B.N. Pandey, K.P. Mishra, A.G. Jagtap, Radioprotection by Macerated Extract of Nigella sativa in Normal Tissues of Fibrosarcoma Bearing Mice, Indian J. Pharm. Sci., 74 (2012) 403-414.

33. R.M. Silverstein, F.X. Webster, D.J. Kiemle, Spectrometric identification of organic compounds, 7th ed., John Wiley \& Sons, Inc, Hoboken, NJ, USA, 2005.
34. A.A.Doolaanea, A.F.Harun, F. Mohamed, Quantification of Nigella sativa Oil (NSO) from Biodegradable PLGA Nanoparticles Using FTIR Spectroscopy, Int. J. Pharm. Pharm. Sci., 6 (2014) 228-232.

35. K. Nivetha, G. Prasanna, GC-MS and FT-IR Analysis of Nigella sativa L. Seeds, Int. J. Adv. Res. Biol. Sci., 3 (2016) 45-54.

36. M.M.B. Almeida, P.H.M. de Sousa, Â.M.C. Arriaga, G.M. do Prado, C.E.d.C. Magalhães, G.A. Maia, T.L.G. de Lemos, Bioactive compounds and antioxidant activity of fresh exotic fruits from northeastern Brazil, Food Res. Int., 44 (2011) 2155-2159.

37. B. Uttara, A.V. Singh, P. Zamboni, R.T. Mahajan, Oxidative Stress and Neurodegenerative Diseases: A Review of Upstream and Downstream Antioxidant Therapeutic Options, Curr. Neuropharmacol., 7 (2009) 65-74.

38. N.R. Madamanchi, A. Vendrov, M.S. Runge, Oxidative Stress and Vascular Disease, Arterioscler Thromb. Vasc. Biol., 25 (2005) 29-38.

39. M. Valko, C.J. Rhodes, J. Moncol, M. Izakovic, M. Mazur, Free radicals, metals and antioxidants in oxidative stress-induced cancer, Chem. Biol. Interact., 160 (2006) 1-40.

40. X.J. Duan, W.-W. Zhang, X.M. Li, B.G. Wang, Evaluation of antioxidant property of extract and fractions obtained from a red alga, Polysiphonia urceolata, Food Chem., 95 (2006) 37-43.

41. W. Brand-Williams, M.E. Cuvelier, C. Berset, Use of a free radical method to evaluate antioxidant activity, LWT-Food Sci. Technol., 28 (1995) 25-30.

42. S. Sangeetha, R. Archit, A. SathiaVelu, Phytochemical Testing, Antioxidant Activity, HPTLC and FTIR Analysis of Antidiabetic Plants Nigella sativa, Eugenia jambolana, Andrographis paniculata and Gymnema sylvestre, Res. J. Biotech., 9 (2014) 65-72.

43. S. Bourgou, R. Ksouri, A. Bellila, I. Skandrani, H. Falleh, B. Marzouk, Phenolic composition and biological activities of Tunisian Nigella sativa L. shoots and roots, C. R. Biol., 331 (2008) 48-55.

44. G. Singh, P. Marimuthu, C.S. de Heluani, C. Catalan, Chemical constituents and antimicrobial and antioxidant potentials of essential oil and acetone extract of Nigella sativa seeds, J. Sci. Food Agric., 85 (2005) 2297-2306.

45. N.B. Thippeswamy, K.A. Naidu, Antioxidant potency of cumin varieties-cumin, black cumin and bitter cuminon antioxidant systems, Eur. Food Res. Technol., 220 (2005) 472-476.

46. N. Şen, Y. Kar, Y. Tekeli, Antioxidant activities of black cumin (Nigella sativa L.) seeds cultivating in different regions of Turkey, J. Food Biochem., 34 (2010) 105-119.

47. D. Kadam, S.S. Lele, Extraction, characterization and bioactive properties of Nigella sativa seedcake, J. Food Sci. Technol., 54 (2017) 3936-3947.

48. A.A. Mariod, R.M. Ibrahim, M. Ismail, N. Ismail, Antioxidant activity and phenolic content of phenolic rich fractions obtained from black cumin (Nigella sativa) seedcake, Food Chem., 116 (2009) 306-312.

49. D. Kadam, N. Shah, S. Palamthodi, S.S. Lele, An investigation on the effect of polyphenolic extracts of Nigella sativa seedcake on physicochemical properties of chitosan-based films, Carbohydr. Polym., 192 (2018) 347-355. 
50. R.S. Mansour, A.K. Nasser, N.Y. Abo, The Effect of different Nigella sativa L. seed (cake) concentrations on leukocytes counts and some serum immunological parameters in calves, Tikrit J. of Pure Sci., 18 (2013) 31-35.

51. Y.Lu, L. Yeap Foo, Antioxidant activities of polyphenols from sage (Salvia officinalis), Food Chem., 75 (2001) 197-202.

52. B. Halliwell, Free radicals and antioxidants-quo vadis?, Trends Pharmacol. Sci., 32 (2011) 125-130.

53. M. Ristow, K. Zarse, A. Oberbach, N. Klöting, M. Birringer, M. Kiehntopf, M. Stumvoll, C.R. Kahn, M. Blüher, Antioxidants prevent health-promoting effects of physical exercise in humans, Proc. Natl. Acad. Sci. U.S.A., 106 (2009) 8665-8670.

54. J.W. Finley, A.-N. Kong, K.J. Hintze, E.H. Jeffery, L.L. $\mathrm{Ji}$, X.G. Lei, Antioxidants in Foods: State of the Science Important to the Food Industry, J. Agricul. Food Chem., 59 (2011) 6837-6846.

55. I. Batini-Haberle, J.S. Rebouças, I. Spasojevi Superoxide Dismutase Mimics: Chemistry, Pharmacology, and Therapeutic Potential, Antioxid. Redox Signal., 13 (2010) 877-918.

56. R. Apak, S. Gorinstein, V. Böhm, K.M. Schaich, M. Özyürek, K. Güçlü, Methods of measurement and evaluation of natural antioxidant capacity/activity (IUPAC Technical Report), Pure Appl. Chem., 85 (2013) 957-998.

57. A.M. Shoieb, M. Elgayyar, P.S. Dudrick, J.L. Bell, P.K. Tithof, In vitro inhibition of growth and induction of apoptosis in cancer cell lines by thymoquinone, Int. J. Oncol., 22 (2003) 107-113.

58. H. Gali-Muhtasib, M. Diab-Assaf, C. Boltze, J. AlHmaira, R. Hartig, A. Roessner, R. Schneider-Stock, Thymoquinone extracted from black seed triggers apoptotic cell death in human colorectal cancer cells via a p53-dependent mechanism, Int. J. Oncol., 25 (2004) 857-866.

59. H. Gali-Muhtasib, W.G.A. Kheir, L.A. Kheir, N. Darwiche, P.A. Crooks, Molecular pathway for thymoquinoneinduced cell-cycle arrest and apoptosis in neoplastic keratinocytes, Anticancer Drugs, 15 (2004) 389-399.

60. M. Roepke, A. Diestel, K. Bajbouj, D. Walluscheck, P. Schonfeld, A. Roessner, R. Schneider-Stock, H. GaliMuhtasib, Lack of p53 augments thymoquinoneinduced apoptosis and caspase activation in human osteosarcoma cells, Cancer Biol. Ther. 6(2007) 160169.

61. O.A. Badary, A.M. Gamal El-Din, Inhibitory effects of thymoquinone against 20-methylcholanthreneinduced fibrosarcoma tumorigenesis, Cancer Detect. Prev., 25 (2001) 362-368.
62. S.H. Jafri, J. Glass, R. Shi, S. Zhang, M. Prince, H. Kleiner-Hancock, Thymoquinone and cisplatin as a therapeutic combination in lung cancer: In vitro and in vivo, J. Exp. Clin. Cancer Res., 29 (2010) 87.

63. J. Yang, X.R. Kuang, P.T. LV, X.X. Yan, Thymoquinone inhibits proliferation and invasion of human nonsmallcell lung cancer cells via ERK pathway, Tumor Biol., 36 (2015) 259-269.

64. A.O. Kaseb, K. Chinnakannu, D. Chen, A. Sivanandam, S. Tejwani, M. Menon, Q.P. Dou, G.P.-V. Reddy, Androgen receptor and E2F-1 targeted thymoquinone therapy for hormone-refractory prostate cancer, Cancer Res., 67 (2007) 7782-7788.

65. G. Lupidi, A. Scire, E. Camaioni, K. Khalife, G. De Sanctis, F. Tanfani, E. Damiani, Thymoquinone, a potential therapeutic agent of Nigella sativa, binds to site I of human serum albumin, Phytomedicine, 17 (2010) 714-720.

66. S. Ivankovic, R. Stojkovic, M. Jukic, M. Milos, M. Milos, M. Jurin, The antitumor activity of thymoquinone and thymohydroquinone in vitro and in vivo, Exp. Oncol., 28 (2006) 220-224.

67. H. Gali-Muhtasib, A. Roessner, R. Schneider-Stock, Thymoquinone: A promising anti-cancer drug from natural sources, Int. J. Biochem. Cell Biol., 38 (2006) 1249-1253.

68. R. Schneider-Stock, I.H. Fakhoury, A.M. Zaki, C.O. ElBaba, H.U. Gali-Muhtasib, Thymoquinone: fifty years of success in the battle against cancer models, Drug Discov. Today, 19( 2014) 18-30.

69. M.M. AbuKhader, Thymoquinone in the clinical treatment of cancer: Fact or fiction?, Pharmacogn. Rev., 7 (2013) 117-120.

70. T. Tsuzuki, Y. Tokuyama, M. Igarashi, T. Miyazawa, Tumor growth suppression by $\alpha$-eleostearic acid, a linolenic acid isomer with a conjugated triene system, via lipid peroxidation, Carcinogenesis, 25 (2004) 14171425.

71. M. Zhang, B. Fang, L.S. Chen, Study on the Antitumor Activity and Structural Changes of Bovine Lactoferrin-Oleic Acid and Linoleic Acid Complex, Chem. Engin. Transact., 46 (2015) 1399-1404.

72. C. Carrillo, M.d.M. Cavia, S.R. Alonso-Torre, Antitumor effect of oleic acid; mechanisms of action. A review, Nutrición Hospitalaria, 27 (2012) 1860-1865.

73. L. Jiang, W. Wang, Q. He, Y. Wu, Z. Lu, J. Sun, Z. Liu, Y. Shao, A. Wang, Oleic acid induces apoptosis and autophagy in the treatment of Tongue Squamous cell carcinomas, Sci. Rep., 7 (2017) 1-11.

74. R.A. Kaskoos, Fatty Acid Composition of Black Cumin Oil from Iraq, J. Med. Plants Res., 5 (2011) 85-89. 